\title{
In the shadow of Alexander the Great: censorship, ideology and contemporary art in Macedonia.
}

\author{
BLACKWOOD, J.
}

2018

This is the author's pre-copyedited version. The final print version can be found at https://www.bloomsbury.com/uk/censoring-art-9781838608118/

This material must not be cited. 


\section{Censoring Contemporary Art in Macedonia}

\section{Introduction}

In this essay, we will consider how censorship affects discourses of contemporary art in the Republic of Macedonia. To do so, we must first outline the cultural, political and social contexts in Macedonia; consider some differing standpoints on what constitutes contemporary art practice in the country; and, having done so, develop in detail two case studies which will allow the reader to gain an understanding of how censorship is deployed as a tactic in erasing, or in rendering illegitimate, critical contemporary art. Although, as we shall see, contemporary art occupies a marginal and, arguably, subterranean position in Macedonia, such censorial interventions are an acknowledgement of its potential to shape cultural debate in a different way.

The censorship we will be discussing here is not of the blunt, totalitarian kind, involving bans, exile, prison or other judicial punishment for the artists concerned. The artists we mention in this text are still working as artists, and have not been subjected to a judicial process on the basis of the work censored. Nonetheless, in the case studies that follow, works of art, commissioned and following all proper legal procedure, have been removed from public scrutiny by being destroyed, on the orders of persons unknown.

The censorship we are concerned with here, is a censorship of deletion and erasure, and the troubling traces of these events remain foremost in the consciousness of critical artists in Macedonia. Moreover, this is a censorship by stealth; those doing the 
censoring have remained anonymous, and therefore beyond democratic accountability. It is a pattern wearily familiar to those observing different 'managed democracies', in the former Communist world, in Central and Eastern Europe. It is also an irony that seems lost on Macedonia's politicians that, in censoring artwork, they give to them a life and notoriety that they might otherwise not have enjoyed, had they been ignored.

To begin, we shall turn to an overview of contemporary art in Macedonia, and in particular, that part of it subject to censorship by those who occupy positions of political and religious power, in Macedonian society. Public art works produced from a position of critical opposition cannot be fully understood without the brief ecology of contemporary Macedonian art that follows.

\section{An Ecology of Contemporary Art in Macedonia}

The Republic of Macedonia voted to secede from the disintegrating former Yugoslav federation on 8 September 1991, and in so doing effected the only peaceful withdrawal from Yugoslavia, of all its six constituent republics. Not that Macedonia's history since independence has been entirely peaceful; the country suffered from a long international isolation in the 1990s, owing to Greek objections to the country's name and flag. ${ }^{1}$ In 2001 an insurgency to the north and west of the country saw a small but vicious war fought between ethnic Macedonians and Albanians, in the short lived so-called Macedonian insurgency. ${ }^{2}$ 
The current political epoch in Macedonia begins in 2006, with the election of a conservative nationalist government under Prime Minister Nikola Gruevski, leader of VMRO-DPMNE, the biggest right wing party in the country. VMRO-DPMNE, which traces its roots to Macedonian secessionist nationalism in the late nineteenth century, ${ }^{3}$ has remained in power ever since, winning four successive elections and currently governing in partnership with the largest party representing the Albanian minority, the DUI. ${ }^{4}$ The political turbulence and popular demonstrations against the government, from May 2015 onwards, derive in part from the questionable legitimacy of some of those election 'victories'.

The type of government represented by VMRO-DPMNE and its allies has been characterised by the social scientist Katerina Kolozova as a 'hybrid regime'. ${ }^{6}$ Kolozova defines a "hybrid regime” in patriarchal terms, as follows:

...Typical of the state model at issue is the centrality of the role of a strong leader, such as Victor Órban in Hungary or Vladimir Putin in Russia. As a rule, it is an authoritarian figure enacting the essentially patriarchal role of paterfamilias whereby the nation is treated as a community of genetic kinship, a 'family' (ethnos as genos) rather than a nation (or demos)... The general trait of the style of ruling is, I would argue, patriarchalism. The latter enables ethnocentrism, religious conservatism and strong state control. ${ }^{7}$

It is Nikola Gruevski who has, since 2006, sought to build for himself an image as a firm but fair paterfamilias; someone not afraid to make necessary reforms, such as the 2009 overhaul of a previously sclerotic and widely ignored tax system, but also someone who defends and defines the ethnic group of which he claims a leading roleMacedonians. It should be noted that, by implication, Gruevski regards the Macedonian nation as congruent with this largest ethnic group, rather than as representing a mix of differing ethnicities and religious beliefs. 
Macedonian people who adhere to the Orthodox Christian faith may well constitute the largest ethno-religious group in the country, but to limit a definition of contemporary Macedonian statehood to this group, by implication, excludes Albanians, Macedonian Muslims, Roma people, and smaller ethnic minorities such as Vlachs, Bosniaks and Turks from ever being regarded as full and equal citizens within the modern Macedonian state. This is a type of nationalism that has been transmitted through 'official' Macedonian culture, more so than in any other sphere of government influence.

It is in this context that we should approach the highly controversial Skopje 2014 programme, publically announced by VMRO-DPMNE planners in February 2010, and which, five years later, is yet to be completed. This scheme is nothing less than the biggest 'neo-classical' and 'Baroque' building scheme anywhere in the world. For proponents of the makeover, Skopje 2014 aims at a truly Macedonian style of architecture; for opponents, it is nothing more than aesthetically and architecturally illiterate kitsch, which has ruined the city.

The aim of this scheme has been to alter, fundamentally, the appearance of late Yugoslav Skopje. The city was eighty percent destroyed by a disastrous earthquake on 26 July 1963, and had to be rebuilt with international help. The renowned Japanese architect Kenzo Tange devised a masterplan for the city centre, arranged according to his architectural principles; ${ }^{8}$ a broader reconstruction plan for the urban area was devised by the Polish architect Adolf Ciborowski, and a Greek architectural practice. 
On the grounds of practicality and cost, only a small part of Tange's vision was completed, around the new railway station, south east of the city centre, whilst Soviet architects built new housing, in the Karpoš area to the west of the city centre; Poles contributed the new museum of contemporary art. Many other nationalities on both sides of the Cold War divide helped either physically, or in kind, in the reconstruction effort.

The aim of the Skopje 2014 scheme, then, is fundamentally a rejection of the modernism and internationalism that characterised the rebuilding of Skopje in the 1960s and the 1970s, and the international atmosphere that some remember in the Yugoslav capital in the 1980s, in the last decade of Yugoslavia. Skopje 2014 is an attempt to re-cast the Macedonian capital physically, and dominate its public spaces ideologically. The architects of Skopje 2014 have sought to over-write or erase the previous appearance of Yugoslav Skopje, and to emphasise what they regard as the national identity of Macedonia. In the words of the anthropologst Andrew Graan:

...(Skopje 2014) houses a cascading set of state goals, each targeted to different audiences: it aims to sculpt Macedonia’s image and boost its international visibility, to 'normalize' and 'Europeanize' the capital, and to assert (ethnic) Macedonian identity against factors perceived to be threatening (i.e.Greeks and ethnic Albanians). By proactively establishing Macedonia’s ‘European’ character among international publics via branding strategies, Macedonian leaders hope to secure economic advantages and also to trump regional and internal challenges to state authority and national authenticity. ${ }^{9}$ 
It is this complicated, delicate and overlapping set of competing cultural discourses that frames the terrain for the production of contemporary art in Macedonia. In response to these circumstances, artists have four broad choices. Firstly, they can seek to take part in the Skopje 2014 re-building process itself, as many artists have chosen to do, for reasons of material gain or ideological conviction.

Artists from late Yugoslav avant-gardists, such as Aleksandar Stankoski, ${ }^{10}$ to relative unknowns such as Valentina Stefanovska, have participated fully both in the ideological justification and material outworking of the Skopje 2014 project. Whilst Stankoski has functioned consciously as an ideologue for the project, the younger Stefanovska has specifically avoided political comment, preferring instead to use the project as a means of exhibiting her sculptural ideas on a grand public scale.

Stefanovska is the author of the centrepiece of the Skopje 2014 project, the monumental bronze Warrior on Horseback (2010/11), commonly known to locals as Aleksandar Veliki (Alexander the Great), as well as a Triumphal Arch, and a sculpture of Filip II of Macedon, within walking distance of this flagship equestrian sculpture.

At the time of writing, the total cost for Skopje 2014, estimated at around $€ 80$ million when the plans were first revealed to public scrutiny, has mushroomed nearly eightfold. A forensic investigation by the on-line journal Balkan Insight, in September 2015, revealed that over $€ 630$ million had been spent on the realisation of Skopje 2014. ${ }^{11}$ 
A second group of artists chooses not to take sides; not to participate in the Skopje 2014 project personally but, equally, not to condemn it either. In many ways, this is an insidious form of self-censorship and is rooted in the pre-independence academic idea that "“great"” art should not be “"political”” art, but rather that any art work produced, should address the audience on its own terms.

Artists from the Renaissance, such as Leonardo or Michelangelo, a French modernist like Henri Matisse, or American pop artists, would be held up in academies of Fine Art as examples of "great" artists addressing their audience in aesthetic, rather than in political terms. By implication, Yugoslav-era artists such as Borko Lazeski ${ }^{12}$, whose work addressed specifically political narratives of the Yugoslav state, can be dismissed as second rate, as the primary motivation for the work can be deemed political. The irony of a parallel silence on the overtly political nature of the Skopje 2014 scheme, tells a story not only about the selective application of modernist aesthetics in judging artworks, but also about the quality of aesthetic debate within contemporary Macedonian educational institutions.

In terms of Macedonian artists' perceptions of art, this apolitical position, taught at Fine Art Academies, is still unchallenged by a significant majority active in producing and consuming art. Evidence for such a position can be found in the widespread appreciation of dead Macedonian painters from the last century, such as Petar Mazev, whose work continues to exert a disproportionate influence on the work of students who were not born at the time of his death in 1993; and reference, in particular, to French and American modernist painters who were most active in the early to mid- 
twentieth century. This is a position partly deriving from self-censorship, and partly from the comparative isolation of Macedonian art, internationally.

A third position is associated with those who work at national institutions and galleries in Macedonia. On paper, there is a strong network of national galleries and museums, with a comprehensible funding system, little changed from Yugoslav times, in place. By common consent, however, national institutions in Macedonia do not function as they should, and have arguably been in crisis for the last decade. There are two reasons for this.

Firstly, there is a lack of managerial and organisational capacity in Macedonian cultural institutions. Directorial appointments are made on the basis of political loyalty rather than professional competence; those still on the staffs of national institutions, who have professional competence, find themselves working to management who have no understanding of or sympathy with development strategies. Further, in a country with around 28fifty per cent unemployment, officially, and up to $50 \%$ according to unofficial figures, the vast majority of all cultural funding has been channelled towards the realisation of Skopje 2014.

Self-evidently, the ideological trajectory of the re-building of the Macedonian capital sees national institutions starved of the funding necessary to develop a genuinely independent or critical discourse on contemporary culture. In the shadow of Alexander, audiences for cultural events have fallen away significantly, as has the ability of national institutions to mount them. In these circumstances, the National Gallery of Macedonia, and the Museum of Contemporary Art, struggle to fulfil their 
basic functions as cultural institutions. Regional galleries such as the 'Marko Čepenkov’ Cultural Centre in Prilep, and independent cultural festivals such as the long established AKTO festival in Bitola, run on little more than enthusiasm in present times ${ }^{13}$.

It may seem remarkable that an independent cultural sector can exist in the circumstances outlined above. It is this small independent group of artists, curators and activists whose work is the obvious target for censorial intervention by the state. Whilst the three broad positions outlined above are recognisable parts of the contemporary cultural ecology in Macedonia, small, and largely marginal, independent cultural activities cannot. These activities have grown exponentially since the end of the last decade, in response to the increasingly non-functional nature of the Macedonian cultural infrastructure, and as part of a growing critique of the 'official' discourses of Macedonian culture associated with the Skopje 2014 project.

Fundamental to this fourth, 'critical' position, is dialogue, debate, discussion, informal co-operation, solidarity, and mutual support. Critical art in Macedonia is also almost entirely self-funded, and part time in nature; it is not possible to make a full time living from art, made from this standpoint. Although there are different approaches within this 'critical' grouping of artists, the focus on mutual support and dialogue is common to all.

Organisations such as Press to Exit, established by Yane Calovski and Hristina Ivanoska in 2004, have sought to provide residency and networking opportunities for local artists; A.R.T I.N.S.T.I.T.U.T (2009-11) and MOMI (2011-present), with a 
shifting cast of artists, develop a practice which focuses on art as a vehicle for emotional and psychological investigations; the satirical, action-based Sviracinje and the choir Raspeani Skopjani use humour, appropriation and the surreal as provocations to critique.

Alongside self-identifying groups such as those listed above, individual practices, such as those of the graphic artist and painter Matej Bogdanovski, and independent critics such as Bojan Ivanov and Nebojša Vilić, add to the mix of people identified with, and active in, the development of critical and independent art practice.

Perhaps most significantly, the grouping KOOPERACIJA, founded in April 2012 and which formally dissolved in the summer of 2015, adopted techniques of institutional critique, political analysis and site-specificity in developing a collectivist response to prevailing cultural conditions. In many ways, KOOPERACIJA operated as far as possible outwith the confines of contemporary visual culture; intervening briefly in a non-art space (Laundromats, empty flats, business premises in between leases) according to a specifically agreed theme or discussion point, and then moving on to the next project. With a founding membership including Gjorgje Jovanovik, Filip Jovanovski, Igor Toševski, OPA, Nikola Uzunovski, KOOPERACIJA, during the three years of their operation, function as a critical, oppositional core to hegemonic cultural and political positions in Macedonia.

The approach of KOOPERACIJA, focused on democratic deficit, institutional critique, the role and status of art practice in neoliberalism, and ownership of space as key issues in the development of their collectively-authored programme. Commenting 
on the possibilities for the artist in Macedonia at the beginning of 2014, the KOOPERACIJA grouping observed that:

Politicians are known to use art as a propaganda tool, but it is the artist who can recognize the manipulations concealed behind these strategies and is capable of exposing the workings of such mechanisms. Therefore, it becomes a responsibility to challenge these and similar issues by any means possible. In this context, art is indeed a powerful tool: it can deliver a high impact by sending a strong message while using simple means. ${ }^{14}$

By the time that this statement was written, three of the artists had direct experience of the spectacular response that such critical actions, based on expressing a clear message in a comprehensible way, could have. These incidents, respectively, are Igor Toševski’s Territory on Plotsad Makedonija, the main square of the nation’s capital, in 2009; and a gently mocking billboard produced by the artistic duo, OPA (Obsessive Possessive Aggression), three years later, as part of an official festival organised by the city of Skopje. We now turn to these incidents, in turn, as examples of the operation of censorship in contemporary Macedonian art.

\section{Case Study: Igor Toševski’s Territory, Plotsad Makedonija, 2009}

Territorieswas a project of the Skopje artist Igor Toševski, an ongoing series of works begun in 2004 and continuing in various locations around the world, in both Europe and America, to 2011. Toševski produced 38 'Territories’ in total. 
Territories revisits the language of Utopian modernism and re-casts this in temporary free locations, in urban spaces. The space of each 'Territory' is delineated by yellow plastic tape which is durable, and which can be easily removed. The future methodology of KOOPERACIJA, of which Toševski was a founder member, can be found here; using simple ephemeral aesthetic means for the strongest impact.

The ideas behind these Territories are fourfold. Firstly, the artist questions the relationship between the individual citizen and public space; how is behaviour regulated and what is possible? According to the rubric of the 'Territory', an activity or object that takes place within its border is considered a work of art. Following on from this, Toševski focuses on the notion of the line as border, as arbitrary symbol of the division between human beings and the different societies in which we live.

Thirdly, the territory is site specific. In each articulation of the 'Territory', the artist grounds contemporary practice in the legacy of the international language of early twentieth-century modernism. Refusing to engage with the limitations of the Macedonian present, he instead confronts his audience with the possibility of imagined alternatives becoming, temporarily, real; the possibility of a different set of social relations and creative interactions. These works also contain a strong relational element, with the documentation and response to each 'Territory' showing how it has been shaped, by those interacting with it.

In the spring and early summer of 2009, Plotsad Makedonija-then an open space whose centrepiece was a circular installation of flowers in the national colours of red and yellow-was the focus of protest and violence. VMRO-DPMNE's plans for the 
antiquizing of the capital's ceremonial square were being discussed in the media and by citizens, with public opinion strongly divided as to the merit of the proposed scheme. In this early articulation of the plans, a space for a monumental Macedonian Orthodox church was envisaged, as a key part of the new architectural layout. It was in this sense that Toševski’s proposed 'Territory' (fig. 1) was calibrated as a pointed intervention, for it occupied exactly the same spot as the site of the proposed church, in the shape of a cross.

The artist recounts that, initially, the whole process for installing the piece went without any problems. Discussions with relevant curators and officials, in the spring of 2009, were amicable and no objections to the scheme were raised. But the artist could not have foreseen that in March and April 2009, tensions were provoked as the extent and nature of the antiquization plans were revealed. Looking back at the incident, in 2015, Toševski observed that '...people saw that the city was about to become a caricature, and they rightly protested. This protest led to an open conflict., ${ }^{15}$ The focus of the protests were differing groups of students, and NGO activists, with Plotsad Sloboda (Free Square) prominent amongst them. The peaceful protests were confronted with violent disorder on 28 March 2011, when a group of Orthodox believers, estimated at 1500, physically assaulted those protesting at the building of the church, with the police standing by idly. ${ }^{16}$ The grim events of the day, with a peaceful demonstration violently dispersed by hooligans, was described by the journalist Harald Schenker as follows: 
On this sunny Saturday, a group of young urbanites was prevented from expressing two of their fundamental rights: the one to gather in peaceful protest, the other to freely express their opinion. And to make it worse - they were "prevented” by blank violence, exercised by a bunch of hooded hooligans - in the name of the church, in the name of Christianity. ${ }^{17}$

The increasing sense of foreboding at the direction the government was taking culminated in the tragic murder of 22year old Martin Nešovski, on 6 June 2011, at the hands of a Macedonian police officer. ${ }^{18}$ Protests against the plans, merged with citizen outrage at Nešovski's death, and demands that individuals and government agencies responsible be held accountable for their actions, continued throughout June and July of that year.

In this fraught political context, Toševski’s territory piece was bound to provoke strong reactions. The unveiling of the piece was scheduled for autumn 2009, as part of a broader exhibition with three German artists. The necessary permits to install an artwork, temporarily, in a public space, were obtained from different levels of city authority. As a final hurdle, the artist had to get the approval of the city mayor of Skopje; this was forthcoming a matter of days before the exhibition opened. The quick process of establishing the artwork in its position was completed, in the presence of police who, with all legal and administrative formalities complete, supervised the work, but did not intervene.

The reaction to this new territory was almost immediate. The work was condemned by the NGO Plotsad Sloboda as a provocation, and this narrative was taken up in the 
local media. Within a matter of hours of the work being completed, un-named government officials ordered the work painted over as a priority, by city council workers. Reflecting on this experience, Igor Toševski said:

...the government ordered the erasing of the yellow cross, and it became the black cross, which was lovely in a way[...]it was a really interesting situation, as everyone saw one another naked[...]I didn’t expect such a reaction, I had done thirty-eight territories before and never encountered such a response. The whole context is important; I suppose it was a good time and a good place, to do this. ${ }^{19}$

The resonance of this work lasted longer than the tense situation in Skopje in 2009. It is important to acknowledge that, whilst this work took place in the context of the beginnings of protest at the Skopje 2014 scheme, it was not a protest against that scheme itself, whose details were not officially announced until February 2010. Rather, this piece was about ownership of public space and, by extension, the divisive use of religion and ethnicity as a means of control in contemporary Macedonian society. As events transpired, the proposed Orthodox church was not built in Plotsad Makedonija, as there simply wasn't the space there for it.

Toševski continued to re-visit the ‘Territory’ notion, with his final work being commissioned in Gdansk, Poland in 2012. He placed a territory outline at a historically significant spot for the trade union and subsequent government party, Solidarnosc (Solidarity). In spite of the historic sensitivities of this piece, the work 
passed off without comment from the authorities, in stark contrast to the experience on Plotsad Makedonjia.

The lessons of Toševski’s quickly-erased artwork are painful. The complete impotence of the country’s cultural institutions to defend a work of art from destruction was cruelly exposed in a display of brute political force. The sad contrast between the destruction of this work in a public place, and the indifference that it would have generated in an indoor gallery space, seen only by a few visitors, was stark.

Further, it revealed the dreadfully low level of public debate surrounding art in Macedonia, and the increasingly violent divisions being torn open amongst the broader public. The role of a work of art is to ask questions, or to invite discussion. Unfortunately, such a debate is of interest only to a vanishingly small number, a small group of well-educated, urban-dwelling citizens. As soon as the resonance and potential power of this particular artwork was recognised by the political and religious establishments, it was destroyed without any further discussion.-This was despite all the necessary permissions having been granted. Further, the possible infringement of the artist's right to freedom of expression and not to have his work destroyed, was raised. Regrettably, in this context, the rights of an individual, de facto if not de jure, come second to the interests of the state. In contemporary Macedonia art works such as this have the effect of shutting down rather than opening out debate about difficult topics.

Case Study: Obsessive Possessive Aggression's Solution, 2012 
In April 2012, many Macedonian Orthodox adherents believed that they had witnessed a miracle, at St. Demetrius Church, one of the oldest churches extant in Skopje. The frescoes on the walls of the church, long stained with dirt, appeared to have cleaned themselves miraculously; the gold haloes of the saints once again shone out brightly in the church interior, without having been cleaned or treated at all. Many who witnessed the transformation claimed the mysterious cleansing as a miraculous event, even if scientists and religious leaders treated the matter more cautiously. Thousands of worshippers came to see the frescoes, which were also the subject of a visit by Prime Minister Gruevski. ${ }^{20}$

Coincidentally, the Macedonian art duo Obsessive Possessive Aggression (OPA), consisting of Slobodanka Stevceska and Denis Saraginovski, had been invited to take part in a festival organised by the Ars Akta organisation, in June 2012. Entitled Skopje Creative Festival, the project featured twelve commissioned billboards, allocated to different artists and designers, to come up with an example of the city's creative potential.

OPA decided to produce a witty response to the miracle incident at St. Demetrius church. (fig. 2) Producing an 'advertisement' for a fake cleaning product, their work showed what appeared to be a cleaning spray placed in front of the outline of eight glowing haloes. Underneath the spray, a strapline text says 'Reaches Even the Most Hard-to-Reach places’. 
Initially, there was little overt response to the work. The key difference between this incident and that involving Igor Toševski three years previously, was the use and increasing popularity of social media in Macedonia, particularly Facebook. Slowly, images of the work began to be shared on social media by users, with many enjoying the sardonic joke at the expense of the alleged miracle, earlier in the year. From social media, television journalists picked up the story, and began to run it on the mainstream media, a rapidly-evolving process which provoked a sudden backlash from the conservative and religious right.

The public debate surrounding the work, in response to items on television, quickly provoked heated online debate. Church officials complained that although the work had been sanctioned by the Skopje Creative Festival, and the billboard space had been paid for, the Church's approval had not been sought before the image had been erected. Rapidly, aggressive, unpleasant and threatening comments began to be left online about this image.

The use of parody, and a cheap, poor, readily comprehensible aesthetic, was morphing rapidly into a full-blown scandal, the scale of which surprised the artists and their peers. Reflecting on the incident in summer 2015, Slobodanka Stevceska observed that:

People became more and more aggressive...people like this have support from higher up. When you discuss religion, it is problematic, as you appear to be attacking their beliefs. When we made the project, we realized it would have 
consequences... but we didn’t think that response would be so intensive. It was a good experience, and good for our work. ${ }^{21}$

From the other side, the KOOPERACIJA grouping, which had had its first public exhibition in a Skopje laundromat in April 2012, rallied all the support they could in defence of the image. By this stage, however, events had taken on their own momentum. The image was unveiled on the 10 June; within 24 hours, an agent, acting on the orders of unknown officials, had ripped the image off the billboard, destroying it totally. As had happened with Toševski, this had provoked further exchanges, on the violent and aggressive tone of the debate, the pointlessness of destroying the art work (the original image is still available to see online for anyone who wishes to find it), and the trampling over the rights of the individual artist, their rights to freedom of speech and not to have their property destroyed.

This image fulfilled three broad functions. Firstly, it encouraged a public response by using a simple, easy to understand image and gentle parodic humour of the alleged miracle at St. Demetrius. Through this humour, OPA sought to open out a broader debate about the power of the image; the power of the church to use religious imagery for manipulative ends, counteracted by the ability of the artist to reveal those networks of power in response.

Further, it opened out discussion on the acceptable boundaries of image making, and on the responsibilities of the artist in a society such as Macedonia. Notions of taste and decency, humour and offensiveness, those who exercise power and those who are subject to the actions of power, were all issues furiously debated in mainstream 
media, and in on-line and social media forums. This was a brief and intense paroxysm of discussion surrounding an artwork that would simply not have taken place, had it been exhibited in a gallery context. Consequently, this is also a work that deals implicitly with self-censorship, and the failure of art institutions and artists to function in any meaningful way. If engagement with the public is an afterthought, then what is the purpose of making the image in the first place?

Finally, this image laid bare the close inter-relationship between church and state, and the unspoken power of the church to affect offense on behalf of their congregation, and demand immediate action accordingly. In the vacuum left by the collapse of Titoist Communism and Yugoslavia, and in a post-ideological age, the church has capitalised adroitly in filling these vacated spaces. The visible destruction of this artwork - exactly the same fate as happened with Toševski’s work- produced an image that was much more powerful and raw than these artists had ever expected. In many ways, the destruction of OPA's billboard was the final manipulation by the Church of the 'miracle' at St. Demetrius.

\section{Conclusion}

'The question remains though: how can art actually participate in society as an instrument of change and as such make a difference? ${ }^{22}$

In this essay, we have provided an ecology of Macedonian contemporary art, in outline, and identified those 'critical' artists who employ mixed strategies of institutional critique, site specificity, and gentle humour, as being most likely to suffer 
some kind of censorship. It would be nice to be able to present our two case studies as isolated and atypical responses to critical contemporary art, but it would also be untrue.

Had there been greater space and time, we could have considered many more examples- the response of the authorities, suing 'outraged citizens' as a proxy, to Velimir Zernovski’s exhibition All Beauty Must Die in 2013, again in Plotsad Makedonija, or, more recently, the refusal of any Macedonian printer to produce a copy of an image produced by Irena Paskali, for another exhibition on advertising billboards, in 2014. More insidious than these actions is the prevailing air of selfcensorship; the quiet accommodations with prevailing political and religious orthodoxies that sees artist either attaching themselves to the antiquization projects of the government or, at the very least, retreat into a kind of twenty-first century 'art for art's sake' position, represented by exhibitions attended by derisory audiences and evincing few if any comments in the mainstream media.

In this sense, then, the ability of critically minded artists to provoke a reaction from both the state and the public, to open out discussion- even if it may be passingly unpleasant discussion, in the form of a social media feeding frenzy-is a precious one. It is precious as it still claims a small public profile for contemporary art in a country where visual culture has been dragooned into the service of a right-wing ethnonationalist view of Macedonian history, and its present neo-liberal reality.

\section{Bibliography / References}


Abadzieva, Sonia Deep Breathing: Aspects of Women's Discourse in 20th century Macedonian Art (Skopje, 2001).

Bocvarova-Plaveska, Marika. (ed.)_Fragments: Macedonian Art Scene 1991-2011 (Skopje, 2011).

Blackwood, J (), Critical Art in Contemporary Macedonia, (Skopje, 2016).

Blackwood, J. and Ivanov, B. , A Parallel Universe: Five Contemporary Artists from Macedonia (Sarajevo, 2014).

Frangovska, A .Transfiguring : Macedonian Contemporary Art (Prague, 2014).

Georgievski, B., 'Ghosts of the Past endanger Macedonia’s future', Balkan Insight. (27 October 2009). Available at:

http://www.balkaninsight.com/en/article/ghosts-of-the-past-endanger-macedonia-sfuture (accessed 1 December 2015)

Graan, Andrew. , 'Counterfeiting the Nation? Skopje 2014 and the Politics of Nation Branding in Macedonia’ Cultural Anthropology, XXVIII/1 (2013), pp. 161-79.

Available at:

https://www.academia.edu/2516725/Counterfeiting the_Nation_Skopje_2014_and_th e_Politics_of_Nation_Branding_in_Macedonia._2013_Cultural_Anthropology_28_1_ $\underline{161-179}$

Ignatova, E., 'Macedonia: Student Protests End in Violence', Global Voices web portal. Available athttps://globalvoices.org/2009/03/31/macedonia-student-protestends-in-violence/

Kolozova, K.,The Uses and Abuses of Neoliberalism and Technocracy in the PostTotalitarian Regimes in Eastern Europe: The Case of Macedonia (Skopje, 2015). Available at http://www.isshsvisualizations.com/uploads/4/2/0/5/42051665/the-usesand-abuses-of-neoliberalism-and-technocracy-in-the-post-totalitarian-regimes-ineastern-europe-the-case-of-macedonia.pdf

Kooperacija. 'Art and Politics? Kooperacija., Reader: Balkans, Open Systems Journal, (2014). Available at: http://www.openspacezkp.org/2013/en/journal.php?j=5\&t=32\#bio

Koteska, J., 'Troubles with History: Skopje 2014', Art Margins Online, (2011). Available at http://artmargins.com/index.php/2-articles/655-troubles-with-history$\underline{\text { skopje-2014 }}$

Marchevska, E.,'Solidarity and Self-Organising as Generators of Change: The Role of Self-Organised Art Initiatives in Macedonia' (2015). Available at http://openengagement.info/tag/macedonia/

Milevska, S. , “Macedonian Art Stories” in IRWIN (eds., 2006), The East Art Map, (London, 2006). 
Milevska, S. and Veličovski, V. , Zero: Retropsective 1984-2009, (Skopje, 2009).

Mijalković, M. and Urbanek, K. , Skopje : The World Bastard (Klagenfurt, 2011).

Risteska, Aneta., 'Critical Voices Erased from Macedonian Arts', Balkan Insight, (6 November 2015). Available at: http://www.balkaninsight.com/en/article/criticalvoices-erased-from-macedonian-arts--11-05-2015

Schenker, Harald., 'Art and Religious Intolerance', Balkan Insight, (14 June 2012). Availableat: http://o-p-a.org/images/Art_and_Religious_Intolerance.pdf

Zantvoort, J. , 'Skopje 2014: Tragedy or Farce?’,Balkanist (3 June 2014). Available at: http://balkanist.net/skopje-2014-tragedy-or-farce/

http://toshevski.weebly.com/

http://o-p-a.org/

http://www.nvilic.wordpress.com

\footnotetext{
${ }_{1}^{1}$ Although Macedonia declared independence in September 1991, it was not officially recognized by the United Nations until 13 April 1993, in the face of Greek objections to the name 'Republic of Macedonia'. From the Greek perspective, this name implies a territorial claim on the Greek region also called Macedonia. It is from this dispute that the country's official name at the United Nations, 'Former Yugoslav Republic of Macedonia' or FYROM, arose, although this formulation is not so commonly used now. The British government refers to the country as 'The Republic of Macedonia' in all diplomatic relations. However, continuing Greek objections have seen the country's accession to supranational political and military bodies, such as the EU and NATO, effectively blocked.

2 The Macedonian insurgency began in late January 2001 and was terminated by the signing of the Ohrid agreement, between the political representatives of the state government and National Liberation Army insurgents, in August 2001. The insurgency claimed 1,000 casualties in total, of whom between 150-250 were killed.

3 VMRO- which stands for Internal Macedonian Revolutionary Organisation- was founded in 1893, and lasted until the middle 1930s when it was forced underground and outlawed, in the Kingdom of Yugoslavia. The present-day VMRO-DPMNE (Internal Macedonian Revolutionary Organisation-Party for Democratic Renewal), is a new party, founded on 17 June 1990, which claims ideological descent from the original grouping.

${ }^{4}$ The DUI (Democratic Union for Integration) was founded in 2001, under the leadership of Ali Ahmeti. The DUI, as a political organization, grew out of the ethnic Albanian National Liberation Army (NLA), which briefly fought with government forces in the 2001 Macedonian insurgency. The military conflict was brought to an end by the signing of the Ohrid agreement, which saw the NLA disarmed, and the DUI, amongst other ethnic Albanian parties, founded.

${ }^{5}$ See BBC World, 'Macedonian Protests; Anti-Gruevski Rally in Skopje', 17 May 2015, available atwww.bbc.co.uk/news/world-europe-32771233.

${ }^{6} \mathrm{~K}$. Kolozova, The Uses and Abuses of Neoliberalism and Technocracy in the Post-Totalitarian

Regimes in Eastern Europe: The Case of Macedonia (Skopje, 2015)., p.7.

7 Ibid, pp. 8-9

8 See Zhongjie Lin , Kenzo Tange and the Metabolist Movement: Urban Utopias of Modern Japan, (Oxford, 2010). See also 'Kenzo Tange's Reconstruction Plan for Skopje'. Available at http://tststsss.tumblr.com/post/8342830969/kenzo-tange-reconstruction-plan-for-skopje
} 
${ }^{9}$ Andrew Graan, 'Counterfeiting the Nation? Skopje 2014 and the Politics of Nation Branding in Macedonia' Cultural Anthropology, XXVIII/1 (2013), p.170.

${ }_{10}$ Stankoski (b. Kičevo, 1959) was a member of the leading contemporary art group, Grupa Zero, based in Skopje, in the 1980s. In present times his practice features a pseudo-historical, mock neoclassical style dealing with some events from Macedonian history. Zero began their activities in Štip in 1984, with the group fizzling out at the beginning of the 1990s. Membership included Igor Toševski, who in an interview with the author remembered the international flavour of late Yugoslav Skopje, with students from the Middle East and North Africa prominent. Other members of Zero included Sinisa Cvetkovski, Miodrag Desovski, Perica Georgiev-Pepsi, Bedi Ibrahim, Zoran Janevski, Tatjana Miljovska, and Zlatko Trajkovski. For more details of Zero's activities see S. Milevska, and V. Veličovski, V., Zero: Retropsective 1984-2009, (Skopje, 2009). 11 See the special investigation of the Balkan Insightweb portal, with its page dedicated to the cost of the Skopje 2014 project, which can be found at : skopje2014.prizma.birn.eu.com/en/. As of 8 December 2015, the cost of the still unfinished project is said to be $€ 633,265,564$.

12 Borko Lazeski (born Prilep 1917, died Skopje, 1993) was a monumental painter and decorative artist who began to develop a specifically left-wing body of work concentrated around Macedonian fishermen in the late 1930s. In the yuears of socialist Yugoslavia, Lazeski was prominent in securing public commission, notably a mural on the National Liberation War for Skopje railway station, destroyed in the July 1963 earthquake; and a mural on the same subject for Skopje's Post Office in the late 1970s. Representations of these works can be found online at http://www3.varesenews.it/blog/labottegadelpittore/?p=318. A version of Lazeski's Monument to the National Liberation War can be seen in the $11^{\text {th }}$ October 1941 Museum in Prilep- see http://whereismacedonia.org/where-to-go-in-macedonia/museums-in-macedonia/426memorial-museum-11th-october-in-prilep. The only text with an English section on Lazeski's work is Sonia Abadzieva's Borko Lazeski, Museum of Contemporary Art, Skopje, 1980.

13 Interview between the author and Filip Jovanovski,

${ }^{14}$ See 'Art and Politics? Kooperacija', (13 January 2014.) Available atwww.openspacezkp.org/2013/en/journal.php?j=5\&t=32\#bio

15 Igor Toševski, interview with the author, Skopje, 23 July 2015; edited transcript in J.

Blackwood,. (Skopje , 2016).

${ }^{16}$ See E. Igantova, 'Macedonia: Student Protests End in Violence', Global Voices web portal. (2009). .

17 Harald Schenker, "Tribal Patients on a Rampage", 30 March 2009. Available at

https://hschenker.wordpress.com/2009/03/30/tribal-patients-on-a-rampage/

${ }^{18}$ See, for example, Elizabeth Flock, "Hundreds Protest Macedonian beating death", The

Washington Post, (7 June 2011), available at

www.washingtonpost.com/blogs/worldviews/post/hundreds-protest-macedonian-beatingdeath/2011/06/07/AGwsJHLH blog.html

In summer 2015, as part of an ongoing campaign of releasing wiretapped evidence covering government corruption, nepotism and malfeasance, the opposition SDSM released compelling evidence that senior Macedonian politicians colluded with state institutions to cover up the exact details of the Nešovski murder. See 'Zaev's Bomb: Nikola Gruevski tried to hide the truth about Martin Nešovski', meta.mk news agency, 5 May 2015. Available at http://meta.mk/en/bombana-zaev-nikola-gruevski-se-obidel-da-ja-uvie-vistinata-za-martin-neshkovski/

${ }^{19}$ Igor Toševski, conversation with the author, 23 July 2015.

${ }^{20}$ See Sinisa Jakov Marusic, 'Macedonian Scientists Ponder Fresco 'Miracle", Balkan insight, 12 April 2012. Available atwww.balkaninsight.com/en/article/science-cautious-aboutmacedonian-miracle

${ }^{21}$ Conversation between OPA and the author, 18 July 2015. Edited transcript in Jonathan Blackwood, Critical Art in Contemporary Macedonia, (Skopje, 2016). (2016).

22 'Art and Politics? Kooperacija', Reader: Balkans, Open Systems journal. Availableat www.openspace-zkp.org/2013/en/journal.php?j=5\&t=32\#bio. 